Available online: https://journals.researchsynergypress.com/index.php/ijebce/ International Journal of Entrepreneurship, Business and Creative Economy (IJEBCE) ISSN 2775-3085 (Online) | 2775-3107 (Print)

Volume 1 Number 1 (2021): 39-56

\title{
Digital Marketing Strategy of Creative Consultant during COVID-19 Pandemic: a Qualitative Approach
}

\author{
Karerin Narisa Putri' ${ }^{1}$, Daniel Hermawan ${ }^{1}$ \\ ${ }^{1}$ Business Administration Department, Parahyangan Catholic University, Indonesia
}

\begin{abstract}
In this research, we aim to explain how creative consultant use digital marketing and the success rate of this marketing strategy, since the digital marketing has improved business strategies to increase productivity and sales, especially during COVID-19 pandemic. Our study used qualitative method and we conduct interview and observation to collect the data. In this study, we use several analysis tools, such as EFE, CPM, IFE, SWOT, SPACE, IE, and QSPM, and our results showed that digital marketing strategy is quite effective from the point of view of promotional and advertising strategies carried out, even though not giving maximum profit as in pre-pandemic. Henceforth, creative consultant needs to use a market penetration strategy to improve their business performance.
\end{abstract}

Keywords: business strategy; creative consultant; COVID-19; digital marketing; market penetration

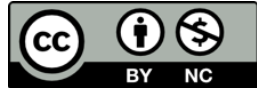

This is an open access article under the CC-BY-NC license.

\section{INTRODUCTION}

The COVID-19 pandemic caused various business sectors to experience a decline in sales. PSBB (Pembatasan Sosial Berskala Besar) policy makes people have to reduce activities outside the home. Businesses that have an activity base with crowds, such as restaurant, shopping center, wedding organizers are the business sectors that most affected by the COVID-19 pandemic. The COVID-19 pandemic has a negative impact on the company's operations, but on the other hand provides new opportunities in digital marketing development.

This makes business have to innovate in offering the products or services they offer. One of them is through digital marketing. Due to the current situation, internet users are increasing. Internet users spend a lot of time online, especially in social media. In Indonesia, there are 132 million active internet users or about $52 \%$ of the population. Of these internet users, there are 129 million who have active social media accounts and spend an average of 3.5 hours per day on internet consumption via smartphone (Diandra, 2020). Digital marketing has improved the mindset of new marketing strategies to increase productivity and sales. Technology has revolutionized the way businesses run significantly, by finding, targeting, serving, and communicating with customers (Glavas \& Mathews, 2014). Digital marketing and social media provide opportunities, especially for businesses to attract customers during this pandemic. The impact of digital technology, companies can take advantage of the opportunities provided by digital technology to create value for their customers and also create value for themselves (Rust, Lemon, \& Narayandas, 2004). 
International Journal of Entrepreneurship, Business and Creative Economy (IJEBCE), Vol. 1 (1), 39-56

Digital Marketing Strategy of Creative Consultant during COVID-19 Pandemic: a Qualitative Approach Karerin Narisa Putri, Daniel Hermawan

Freelens Studio was selected purposively using snowball sampling as the object in this study considering that it can represent a creative company that has grown significantly in the last 4 years. Based on client experience as a user, Freelens Studio is also able to provide good quality services in the field of digital marketing.

Therefore, Freelens Studio tries to answer the phenomenon where nowadays businesses need a digital marketing communication strategy to increase sales productivity. Freelens Studio itself was established before the COVID-19 pandemic, established since 2016 and has become a creative consultant. Freelens Studio is a business that offers video making services since 2016, especially a video marketing through digital media.

Freelens Studio also utilizes the video service in digital marketing for its business activities, for example on social media (Instagram, Twitter, and also YouTube). To keep up with the current situation, Freelens Studio is developing its business not only providing video marketing services, as a creative consultant and his company's vision is to help people according to their needs and in delivering their message, Freelens Studio provides several other alternative digital marketing services to help its clients, for example in terms of branding, social media, and also content marketing. Based on the background above, we want to explore digital marketing conducted by Freelens Studio as a creative consultant during COVID-19 pandemic.

\section{LITERATURE REVIEW}

Digital marketing is a new approach to marketing, not just traditional marketing driven by the digital element (Järvinen, Töllinen, Karjaluoto, \& Jayawardhena, 2012). Digital marketing can be classified in a variety of ways. One way to classify the marketing channel is to present it based on the company's point of view or target audience, namely one-way communication channels or twoway communication channels.

\section{One-way Communication Channels}

Website and e-mail are communication tools that can be seen as examples of one-way online tools (Christodoulides, 2009). E-mail can be used for a variety of marketing purposes as well as being a marketing communication tool, including information sharing, promotion, building, and maintaining relationships with customers and guiding customers to the company's website (Simmons, 2007). Whereas e-mail is a two-way communication, but marketers often use email as a one-way communication tool to send offers or advertisements.

Marketers will send ads to offer multiple products so that the ads and offers can be accepted by customers so that customers can get information from the e-mail. Website is also a means to share or search for information through the internet. The website itself can be edited until monitored using SEO (Search Engine Optimization). SEO is a service that can help companies to develop websites and optimize the web to get top rankings in search results.

\section{Two-way Communication Channels}

Social media has become an important part of marketing communications (Bruhn, Schoenmueller, \& Schäfer, 2012). Social media is a successful tool for building brands and attracting customers and building relationships with consumers. Social media is no longer a one-way media as a tool to convey information or advertising, but it can also make it as a 
two-way communication tool more effectively. If social media is used consistently, it can attract awareness and maintain relationships with customers (customer engagement). In addition, the use of social media can also drive the sales rate (Rishika, Kumar, R., \& Bezawada, 2013). An example is Facebook, Facebook has become a communication channel that includes two-way communication tools that have engaged consumers and created awareness of brands (branding) (Malhotra, Kubowicz Malhotra, \& See, 2013). But not only Facebook, other social media such as Twitter, Instagram, etc. can be a two-way communication tool to convey information and build relationships with customers.

According to a recent study on SMEs in the US, social media such as Facebook and Twitter are the most popular social media, while the use of blogging and the use of LinkedIn (used by about half of SMEs surveyed) (Moyle, 2012). Blogging is also said to be a good communication tool for marketing and public relations (Ahuja \& Medury, 2010) . Blogging is another way to create content on the web, even though it requires additional capabilities and work, i.e. companies load company profiles, content, news, offers to product sales on the web.

\section{Digital Marketing Methods}

In the digital world, business want to promote their products and services, in order to survive in conditions of intense competition and different from their competitors, businesses implement digital marketing according to their own interests and objectives. With the help of digital marketing tools, customers can access information about the products or services they want by using digital platforms whenever and wherever they want (Yasmin, Tasneem, \& Fatema, 2015). Digital marketing tools can be grouped into Earned Media, Paid Media, and Owned Media.

\section{Earned Media}

Earned media is when a user or customer (not just a target audience) shares content, disseminates information by word of mouth, and generally discusses brands, products, or services. This earned designation is either negative or positive, which means it is given voluntarily by others (Gateway, 2018).

\section{Paid Media}

Paid media is a space or content that companies pay to advertise on media (Gateway, 2018). In addition to the display of ads on social media, the media obtained includes retargeting, pay-per-click, paid reviews on dedicated blogs, or recommendations from influencers on social media. The paid media helps the development of content for and increase sales of products or services (Machado \& Paulo, 2016).

\section{Owned Media}

Owned media is a platform that the company has that is fully controlled and does not need to be paid. Such platforms are like websites, or social media (YouTube, Instagram, Twitter) (Gateway, 2018). Each of these media offers its own advantages and objectives. All of them contribute to the development of digital marketing strategies, although each company must analyse what media is more suitable for them.

A number of studies show that digital marketing has a significant impact on the implementation of corporate strategies, especially in difficult times, such as the COVID-19 
International Journal of Entrepreneurship, Business and Creative Economy (IJEBCE), Vol. 1 (1), 39-56

Digital Marketing Strategy of Creative Consultant during COVID-19 Pandemic: a Qualitative Approach Karerin Narisa Putri, Daniel Hermawan

pandemic. This is in line with Patel \& Malpani's (2020) research, highlighting that the application of digital marketing will have a positive impact when it is delivered with a positive and relevant message according to the target market. In addition, marketing during the COVID-19 pandemic also requires intense interaction with customers and empathy not to appear rushed in the process of selling products / services. Santoso (2020) underlines digital marketing as a means to increase brand awareness during the COVID-19 pandemic. In addition, digital marketing also changes consumer behavior in interacting with brands more closely, and can increase the purchase potential of potential customers who are exposed to digital marketing content (Arzhanova, Beregovskaya, \& Silina, 2020).

\section{RESEARCH METHOD}

We use qualitative method with descriptive research analysis. Descriptive research analysis is a scientific way used to obtain or obtain data used for a particular purpose (Sugiyono, 2014). The author chose to use this type of descriptive research because researchers wanted to research the right marketing strategies for Freelens Studio in running its business. We want to confirm Porter Five Forces Analysis in this context.

Freelens Studio chosen in this study because in the young age of the company which is 4 years, Freelens Studio can get quite a lot of clients and a large company. This study only discusses one digital marketing company, namely Freelens Studio, considering that we want to dig deep insights and information. In addition, Freelens Studio was chosen to consider the suitability of research topics with case studies. So we interested to see how Freelens Studio implementing digital marketing strategy during COVID-19 pandemic.

The research method is carried out in stages starting with the determination of topics, data collection and analyzing data, also conclusion and recommendation. Validity and reliability testing in this study uses a number of tests, including credibility, transferability, dependability, and confirmability (Sugiyono, 2018). Credibility test is carried out by extending observations and triangulation of techniques. Transferability test allows for the application of digital marketing strategies by creative consultants under conditions similar to Freelens Studio. Depenability test is carried out by a research audit process which is carried out continuously from beginning to end with documentation of the interview and observation process. Confirmability test is carried out by ensuring that interviews and observations are carried out according to the established study protocols.

\section{FINDINGS AND DISCUSSION}

\section{Porter Five Forces Analysis}

We use Porter Five Forces Analysis to analyze our findings. In Figure 1, Freelens Studio facing several conditions, start from low bargaining power of suppliers, low potential entry of new competitors, high bargaining power of buyers, medium potential development of substitutes product, and high rivalry among existing competitors.

a. Rivalry among Existing Firms

In general, competition in the field of Freelens Studio services can be said very intense because many companies are engaged in this field. The main strengths of competitors are different styles or idealisms. But competitors also have weaknesses, namely not having a 
International Journal of Entrepreneurship, Business and Creative Economy (IJEBCE), Vol. 1 (1), 39-56 Digital Marketing Strategy of Creative Consultant during COVID-19 Pandemic: a Qualitative Approach Karerin Narisa Putri, Daniel Hermawan

clear structure. To face competition from companies similar to Freelens Studio, the company uses ways by strengthening relationships with clients, strengthening the company's identity, and customer retention into actions taken by Freelens Studio to keep clients using Freelens Studio services. Here is a comparison table of the profiles of competitors Freelens Studio presented in table 1.

Low

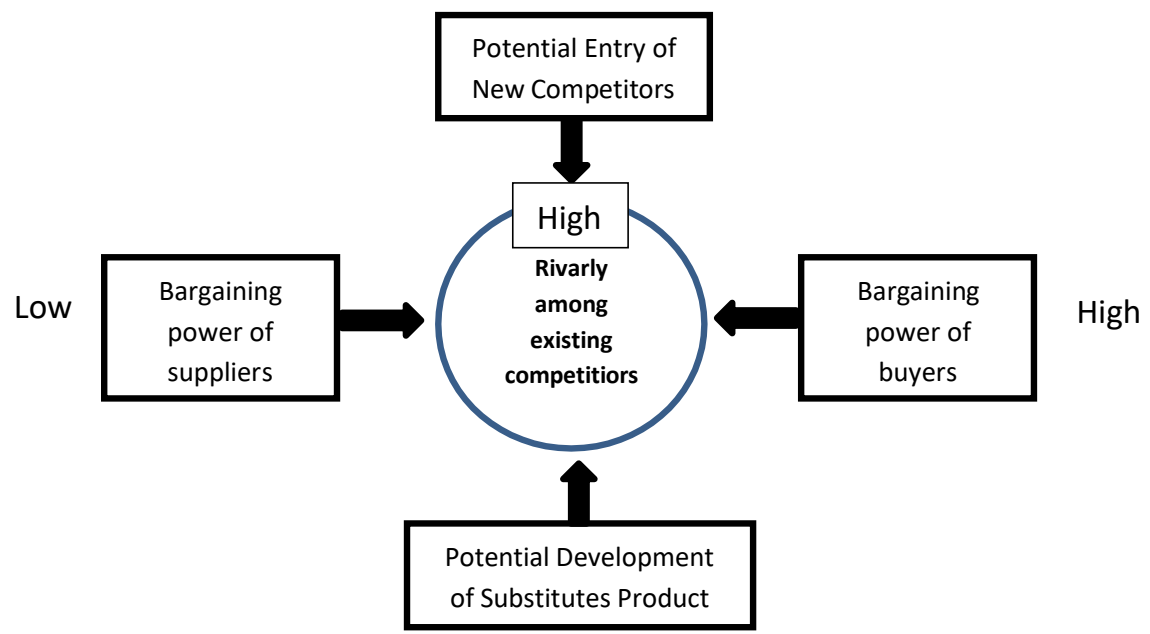

Figure 1: Porter Five Forces Analysis

Table 1. Competitors Analysis of Creative Consultant

\begin{tabular}{|c|c|c|c|}
\hline Description & Freelens Studio & Maika Collective Studio & Sanrok Studio \\
\hline $\begin{array}{l}\text { Types of } \\
\text { Services }\end{array}$ & $\begin{array}{l}\text { Digital advertising } \\
\text { video } \\
\text { Web Series } \\
\text { Film } \\
\text { Fashion Video } \\
\text { Music Video } \\
\text { Branding } \\
\text { Visual Graphics \& } \\
\text { Design } \\
\text { Animation } \\
\text { Social Media Activation }\end{array}$ & $\begin{array}{l}\text { Creative Consultation } \\
\text { Art Direction } \\
\text { Branding } \\
\text { UI/UX } \\
\text { Packaging } \\
\text { Video Production } \\
\text { Illustration } \\
\text { Web Design } \\
\text { Photography } \\
\text { Experience Design } \\
\text { Art Installations } \\
\text { Multimedia Content }\end{array}$ & $\begin{array}{l}\text { Branding } \\
\text { Books \& Print } \\
\text { Art } \\
\text { Event \& Exhibition Fashion } \\
\text { \& Goods Social Media } \\
\text { Video \& Animation } \\
\text { Residential \& Property } \\
\text { Service \& Startup }\end{array}$ \\
\hline Location & Bandung & Jakarta & Bandung \& Jakarta \\
\hline $\begin{array}{l}\text { Promotional } \\
\text { Media }\end{array}$ & Instagram, YouTube & $\begin{array}{l}\text { Instagram, YouTube, } \\
\text { Behance, Soundcloud }\end{array}$ & Instagram, YouTube \\
\hline Social Media & $\begin{array}{l}\text { Instagram, YouTube, } \\
\text { LinkedIn, Twitter }\end{array}$ & $\begin{array}{c}\text { Instagram, YouTube, } \\
\text { Facebook }\end{array}$ & $\begin{array}{l}\text { Instagram, YouTube, } \\
\text { LinkedIn }\end{array}$ \\
\hline
\end{tabular}


Maika Collective Studio and Sanrok Studio are direct competitors of Freelens Studio in similar companies. But as the owner of Freelens Studio said there are still many competitor companies similar to Freelens Studio. The number of similar companies with Freelens Studio and competition makes the competition conditions are quite tight, where each company provides creativity and innovation to each type of services offered, the quality of services, content marketing, and promotional media carried out to compete.

\section{b. Bargaining Power of Supplier}

Not only buyers, suppliers also have an important role in a business, as well as for Freelens Studio. Investors became suppliers to Freelens Studio. Because Freelens Studio uses IP (Intelectual Property), and the possibility of selling the IP to investors, so the performance of outside investors to get inside becomes very supported for Freelens Studio. Every business activity that is assembled with IP is an asset for the company and is an important factor in the development of the company's strategy and competitiveness.

\section{c. Bargaining Power of Buyers}

Tight competition in the digital era makes companies see promotional activities as an important part of the company's strategy. Therefore, the demand for services for digital marketing, video making to branding services becomes important because digital promotional activities become the part of company's strategy to market its products. Companies that offer this services are lots, so the bargaining power of buyers is high and can easily switch because of the large number of service providers similar to Freelens Studio. The higher the bargaining power of the buyer demands a lower price or higher product quality, the lower the profit or profit that will be obtained by Freelens Studio.

\section{d. Potential Entry of New Competitors}

The influence of new competitors on the same field for Freelens Studio certainly exists but has no direct effect. To start a business in the same service field as Freelens Studio requires skills that cannot be learned in a short time, consumers are more likely to want companies that have experience. So the entry of new competitors in the same field as Freelens Studio has no direct effect. Except when a new competitor has technology such as computers, cameras, and other applications that are better than Freelens Studio it becomes one of the obstacles because it requires a fairly high capital and new competitors can easily get clients in the same field as Freelens Studio.

But for Freelens Studio, brand experience of Freelens Studio itself has advantages over new competitors because Freelens Studio already has better experience and skills than new competitors because it cannot be obtained in a short time. It can be said that new competitors are not very influential in Freelens Studio. However, the entry of new competitors in this field is a motivation for Freelens Studio to always prioritize and improve its quality.

\section{e. Potential Development of Substitutes Product}

Authorization in content creation becomes a substitute threat to Freelens Studio, especially authorization in video creation. Moreover, today's technological advances are still growing. Another substitute threat to Freelens Studio is when people stop selling. Especially because of the COVID-19 pandemic, many businesses are experiencing a decrease in revenue until they go bankrupt, therefore businesses are decreasing. It had a huge influence on Freelens 
Studio. To overcome this, Freelens Studio adjusts its needs and adjusts what Freelens Studio can provide to businesses that do need Freelens Studio services. To adjust these needs, Freelens Studio opens video making services specifically for MSMEs, so that businesses from the lower middle class can also use Freelens Studio services in accordance with their budget.

From each of the 5 factors above, an overview is shown to determine each value. Whether low, medium or high.

(1) In rivalry among existing firms it showed high because there's a lot companies are engaged in the field.

(2) In the bargaining power of supplier shows low because Freelens Studio uses IP (Intelectual Property), and the possibility of selling the IP to investors, so the performance of outside investors to go inside becomes very supported for Freelens Studio.

(3) In the power of bargaining power buyers show high because the tight competition in the digital era of demand for services becomes much needed.

(4) In the entry of new competitors shows low because the influence of new competitors on the same field for Freelens Studio certainly exists but has no direct effect.

(5) In product threat substitution shows moderate due to the current technological advances that continue to grow, so authorization in video creation becomes a replacement threat at Freelens Studio. Especially because of the COVID-19 pandemic, many businesses are experiencing a decrease in revenue until it goes bankrupt it affects Freelens Studio because businesses are decreasing.

After mapping the condition of Freelens Studio externally, we will examine the internal conditions of Freelens Studio in digital marketing in the form of a fishbone diagram. Fishbone diagrams are used to map the causes and effects of problems that exist within the company.

\section{Fishbone Diagram}

Fishbone diagram is a diagram that serves to identify and organize possible causes from a specific effect and then separate from the root cause. We create fishbone diagram to help identify the root of a problem. From the causes that may be the cause of marketing strategies have not supported the client, the company needs to pay attention to these causes and continue to try new strategies. For example, companies need to pay attention to the content part that needs to be made more interesting, work equipment or technology that needs to be updated to support the work process, improve management activities, develop worker skills by always doing work evaluation or selfdevelopment so that it can produce work processes on time, and observe external environmental factors to be used as an evaluation of the company so that the company becomes more creative and innovative than competitors.

In the next stage we conduct business strategy analysis, since we want to do an in-depth study of the implementation of a comprehensive digital marketing strategy in terms of internal and external aspects of the company, and map the most suitable strategies for Freelens Studio to implement after analyzing this business strategy. 
International Journal of Entrepreneurship, Business and Creative Economy (IJEBCE), Vol. 1 (1), 39-56 Digital Marketing Strategy of Creative Consultant during COVID-19 Pandemic: a Qualitative Approach Karerin Narisa Putri, Daniel Hermawan

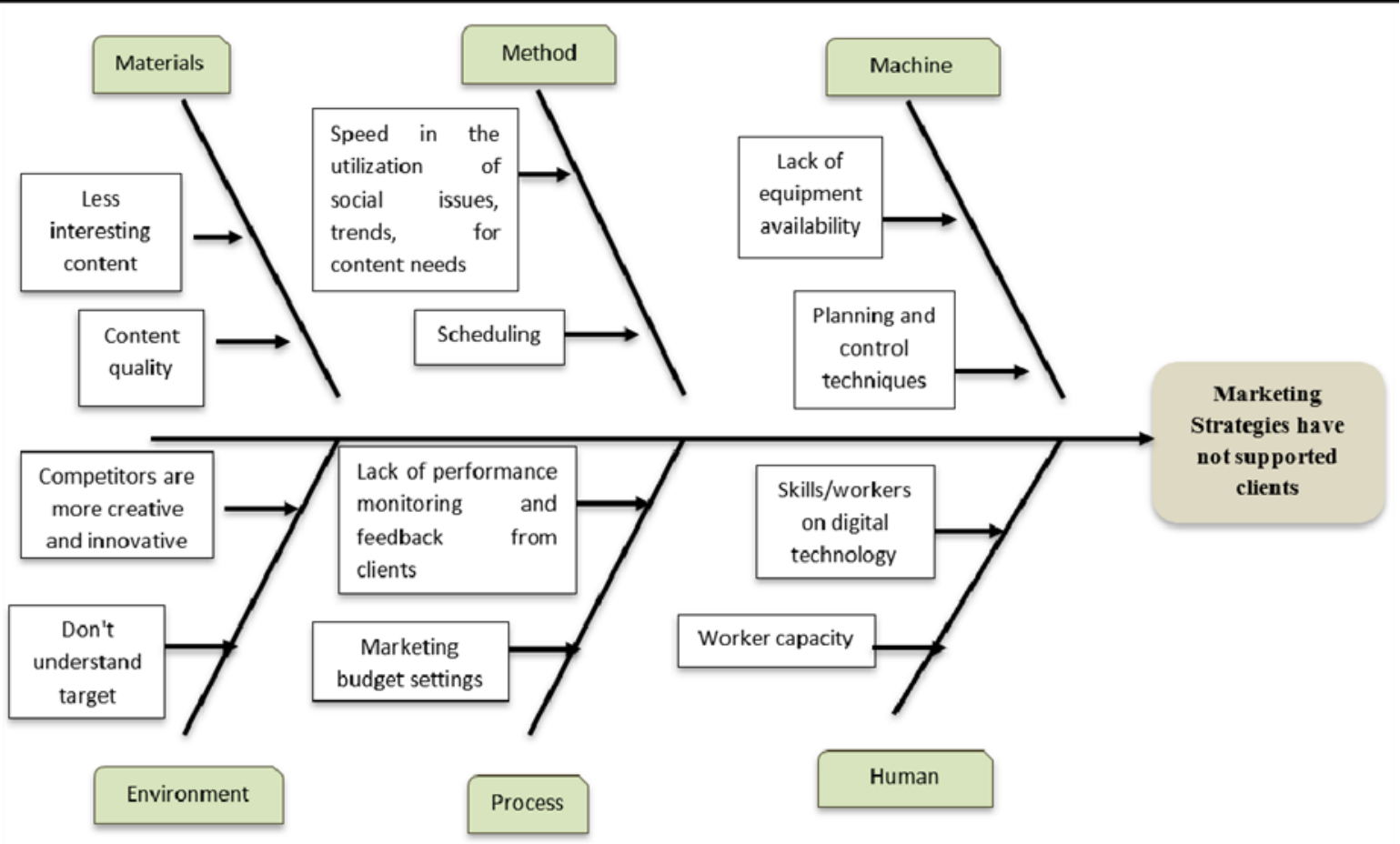

Figure 2: Fishbone Diagram of Freelens Studio

\section{Business Strategy Analysis}

The framework in the formulation of a comprehensive strategy can be described as follows:

Table 2: Research Analysis Design

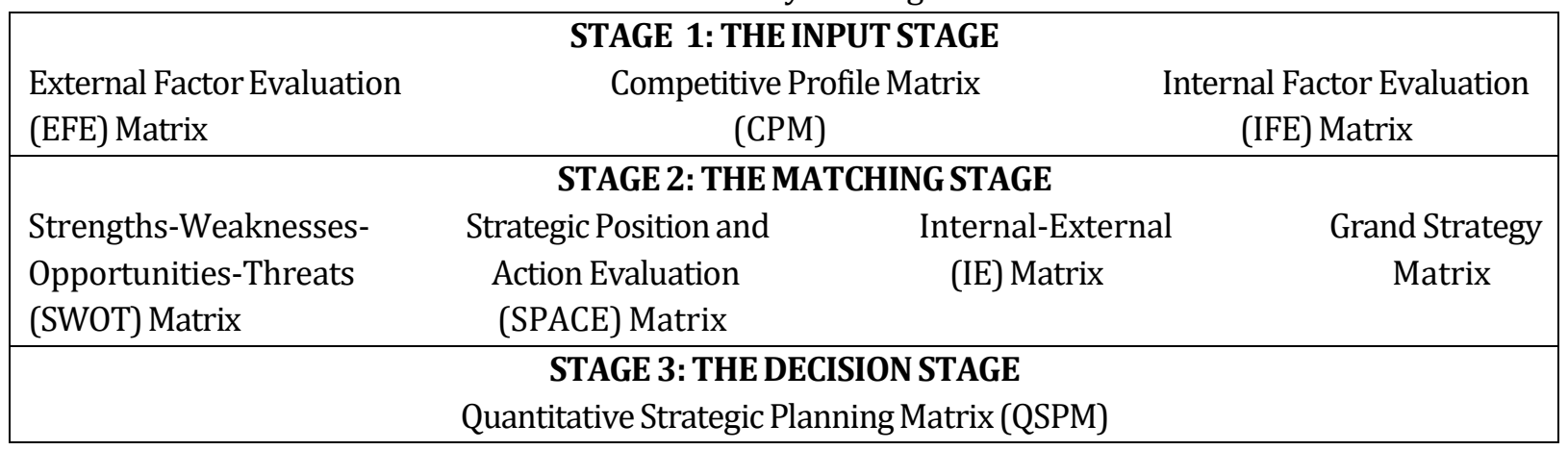

The input stage is the information generated from EFE Matrix, CPM, and IFE Matrix are input for the next strategy formulation process. The selection of truly relevant internal and external factors helps the strategy formulation process to be much more effective.

The matching stage defined as a match for the internal and external factors faced by the organization. Techniques used in the matching process include: SWOT Matrix, SPACE Matrix, IE Matrix, and Grand Strategy Matrix. These techniques rely on information obtained from the input stage to match external opportunities and threats with internal strengths and weaknesses. The decision stage is analysis and intuition that provides the basis in decision making related to the strategy to be chosen. The better the analytical ability and intuition, the greater the possibility of the strategy chosen is the best strategy. 
International Journal of Entrepreneurship, Business and Creative Economy (IJEBCE), Vol. 1 (1), 39-56

Digital Marketing Strategy of Creative Consultant during COVID-19 Pandemic: a Qualitative Approach Karerin Narisa Putri, Daniel Hermawan

\section{EFE Matrix Analysis}

The EFE matrix is used to knowing how much influence it has on external factors of Freelens Studio. Total weighted values on the matrix this is the result of the total sum of the multiplication of weights and ratings of each external strategic factors of Freelens Studio.

Table 3: EFE Freelens Studio Matrix Table

\begin{tabular}{|l|c|c|c|}
\hline \multicolumn{1}{|c|}{ External Factors } & Weight & Rating & Weights \\
\hline \multicolumn{1}{|c|}{ Opportunities } & \multicolumn{2}{|c|}{} \\
\hline COVID-19 pandemic boosts digital marketing business & 0,2 & 2 & 0,4 \\
\hline $\begin{array}{l}\text { Development of technology and information in the creation of } \\
\text { digital content marketing that continues to grow }\end{array}$ & 0,2 & 3 & 0,6 \\
\hline Launch a new product or service & 0,2 & 3 & 0,6 \\
\hline \multicolumn{1}{|c|}{ Threats } & & & \\
\hline Competitors of similar companies & 0,1 & 3 & 0,3 \\
\hline Lack of awareness of Consumer Product Knowledge & 0,2 & 1 & 0,2 \\
\hline Declining business dynamics of the business world & 0,1 & 2 & 0,2 \\
\hline \multicolumn{1}{|c|}{ Total } & $\mathbf{1}$ & & $\mathbf{2 , 3}$ \\
\hline
\end{tabular}

The weight and rating obtained in the EFE matrix is based on interviews and discussions between researchers and owner of Freelens Studio.

\section{Competitive Profile Matrix (CPM) Analysis}

Table 4: Competitive Profile Matrix (CPM) Analysis

\begin{tabular}{|l|c|c|c|c|c|c|c|}
\hline & & \multicolumn{2}{|c|}{ Freelens Studio } & \multicolumn{2}{c|}{$\begin{array}{c}\text { Maika Collective } \\
\text { Studio }\end{array}$} & \multicolumn{2}{c|}{ Sanrok Studio } \\
\hline Critical Success Factors & Weight & Rating & Score & Rating & Score & Rating & Score \\
\hline Types of Services & 0,15 & 3 & 0,45 & 3 & 0,45 & 4 & 0,6 \\
\hline Promotional Media & 0,15 & 2 & 0,3 & 4 & 0,6 & 2 & 0,3 \\
\hline Organizational Structure & 0,2 & 3 & 0,6 & 2 & 0,4 & 3 & 0,6 \\
\hline Service Information & 0,15 & 3 & 0,45 & 3 & 0,45 & 3 & 0,45 \\
\hline Brand Identity & $\mathbf{0 , 2}$ & 3 & 0,6 & 4 & 0,8 & 3 & 0,6 \\
\hline Brand Experience & $\mathbf{0 , 1 5}$ & 4 & 0,6 & 4 & 0,6 & 4 & 0,6 \\
\hline \multicolumn{1}{|c|}{ Total } & $\mathbf{1}$ & & $\mathbf{3}$ & & $\mathbf{3 , 3}$ & & $\mathbf{3 , 1 5}$ \\
\hline
\end{tabular}

According to CPM matrix, Maika Collective Studio is the most superior company between Freelens Studio and Sanrok Studio. Even so, each company has its own advantages and disadvantages. For example, at Maika Collective Studio, they excel between the two companies but are weak on their organizational structure. That's because on the website, social media Maika Collective Studio does not provide clear information about the organizational structure of the company.

\section{IFE Matrix Analysis}

The IFE matrix is used to knowing how much influence it has on internal factors of Freelens Studio. Total weighted values on the matrix this is the result of the total sum of the multiplication of weights and ratings of each internal strategic factors of Freelens Studio. 
International Journal of Entrepreneurship, Business and Creative Economy (IJEBCE), Vol. 1 (1), 39-56

Digital Marketing Strategy of Creative Consultant during COVID-19 Pandemic: a Qualitative Approach Karerin Narisa Putri, Daniel Hermawan

Table 5: IFE Matrix Analysis

\begin{tabular}{|c|c|c|c|}
\hline Internal Factors & Weight & Rating & Weights \\
\hline \multicolumn{4}{|l|}{ Strength } \\
\hline Have a clear organizational structure & 0,2 & 3 & 0,6 \\
\hline Flexible work ecosystem & 0,2 & 3 & 0,6 \\
\hline Have creative and innovative human resources & 0,25 & 4 & 1 \\
\hline \multicolumn{4}{|l|}{ Weakness } \\
\hline Limited networking & 0,05 & 3 & 0,15 \\
\hline Limited capital in technology investment & 0,2 & 2 & 0,4 \\
\hline Limited service type & 0,1 & 2 & 0,2 \\
\hline Total & 1 & & 2,95 \\
\hline
\end{tabular}

The weight and rating obtained in the IFE matrix is based on the results of interviews and discussions between researchers and owner of Freelens Studio.

\section{SWOT Matrix Analysis}

Table 6: SWOT Matrix Freelens Studio

\begin{tabular}{|c|c|c|}
\hline & Strength & Weakness \\
\hline & $\begin{array}{l}\text { 1. Have a clear organizational } \\
\text { structure } \\
\text { 2. Flexible work ecosystem } \\
\text { 3. Have creative and innovative } \\
\text { human resources }\end{array}$ & $\begin{array}{l}\text { 1. Limited networking } \\
\text { 2. Limited capital in technology } \\
\text { investment } \\
\text { 3. Limited-service type }\end{array}$ \\
\hline Opportunity & Strategy So & Strategy WO \\
\hline $\begin{array}{l}\text { 1. COVID-19 pandemic } \\
\text { boosts digital marketing } \\
\text { business } \\
\text { 2. Development } \\
\text { technology }\end{array}$ & $\begin{array}{l}(01,02, \mathrm{~S} 3,) \\
\text { 1. Conduct product launches in } \\
\text { the form of collaboration with } \\
\text { a brand, or company. For } \\
\text { example, collaboration with } \\
\text { influencers, food brands, }\end{array}$ & $\begin{array}{l}\text { (W1, W3, 01, 02) } \\
\text { 1. Grow your business through } \\
\text { networking by using social } \\
\text { media to acquire business } \\
\text { networks. In addition to } \\
\text { discovering new insights }\end{array}$ \\
\hline $\begin{array}{l}\text { information in the creation of } \\
\text { digital content marketing that } \\
\text { continues to grow } \\
\text { 3. Launch a new product or } \\
\text { service }\end{array}$ & $\begin{array}{l}\text { fashion and so on. To develop } \\
\text { connections to merge } \\
\text { companies to further develop, } \\
\text { gain new audiences, can } \\
\text { expand new markets and } \\
\text { innovations. } \\
2 . \text { Improving the quality of } \\
\text { services by strengthening } \\
\text { customer service skills. By } \\
\text { increasing interaction with } \\
\text { clients, and strengthening } \\
\text { service strategies to clients to } \\
\text { create customer loyalty. }\end{array}$ & $\begin{array}{l}\text { about the business, it can find } \\
\text { out what the target client } \\
\text { really wants and needs. } \\
\text { 2. Develop technology to } \\
\text { maximize the work process } \\
\text { with good task management } \\
\text { through technology. For } \\
\text { example using various } \\
\text { software and applications. } \\
\text { 3. Add the creative teams, } \\
\text { research (business } \\
\text { development), or marketing } \\
\text { to develop creativity, ideas, }\end{array}$ \\
\hline
\end{tabular}


International Journal of Entrepreneurship, Business and Creative Economy (IJEBCE), Vol. 1 (1), 39-56 Digital Marketing Strategy of Creative Consultant during COVID-19 Pandemic: a Qualitative Approach Karerin Narisa Putri, Daniel Hermawan

\begin{tabular}{|c|c|c|}
\hline & & $\begin{array}{l}\text { and also improve the type of } \\
\text { services and services. }\end{array}$ \\
\hline Threat & Strategy ST & Strategy WT \\
\hline $\begin{array}{l}\text { 1. Competitors of similar } \\
\text { companies } \\
\text { 2. Lack of awareness of } \\
\text { Consumer Product } \\
\text { Knowledge } \\
\text { 3. Declining business } \\
\text { dynamics of the business } \\
\text { world }\end{array}$ & $\begin{array}{l}\text { 1. Because of the many } \\
\text { competitions of similar } \\
\text { companies, Freelens Studio } \\
\text { can develop the skills of its } \\
\text { employees through training } \\
\text { programs, or also conduct } \\
\text { benchmarking to strengthen } \\
\text { the brand, evaluate, develop } \\
\text { the type of services, improve } \\
\text { the performance of Freelens } \\
\text { Studio or its production } \\
\text { process. } \\
\text { 2. Freelens Studio can hold or be } \\
\text { part of marketing events. Such } \\
\text { events can be exhibitions, } \\
\text { collaborations and even } \\
\text { concerts. For example, with } \\
\text { fashion brands, electronics. } \\
\text { For example, when one brand } \\
\text { will launch a new product, } \\
\text { Freelens Studio can be part of } \\
\text { the product launching event as } \\
\text { the maker of video advertising } \\
\text { services for the brand. So is the } \\
\text { concert event. For example, } \\
\text { with LaLaLa Fest. This can } \\
\text { increase brand awareness and } \\
\text { expand the business network. }\end{array}$ & $\begin{array}{l}\text { (W2, W3, T1, T2,) } \\
\text { 1. Maximize promotional } \\
\text { activities to gain new clients } \\
\text { or wider market share. } \\
\text { 2. Maximize the use of } \\
\text { resources regarding potential } \\
\text { client targets so that Freelens } \\
\text { Studio precisely determines } \\
\text { what is an opportunity and } \\
\text { what potential target clients } \\
\text { need. }\end{array}$ \\
\hline
\end{tabular}

\section{Strategic Position Matrix Analysis and Action Evaluation (SPACE)}

Table 7: SPACE Matrix Table

\begin{tabular}{|l|c|l|c|}
\hline \multicolumn{2}{|c|}{ Internal Strategic Position } & \multicolumn{2}{c|}{ External Strategic Position } \\
\hline Financial Position (FP) & Rating & \multicolumn{1}{|c|}{ Stability Position (SP) } & Rating \\
\hline Revenue Growth & 5 & Technological developments & -4 \\
\hline
\end{tabular}


International Journal of Entrepreneurship, Business and Creative Economy (IJEBCE), Vol. 1 (1), 39-56 Digital Marketing Strategy of Creative Consultant during COVID-19 Pandemic: a Qualitative Approach Karerin Narisa Putri, Daniel Hermawan

\begin{tabular}{|c|c|l|c|}
\hline Working Capital & 3 & $\begin{array}{l}\text { Increasingly intense competition in } \\
\text { the digital services industry }\end{array}$ & -5 \\
\hline Liquidity Ratio & 5 & $\begin{array}{l}\text { The difficulty of new companies to } \\
\text { get in. }\end{array}$ & -3 \\
\hline Solvency Ratio & 4 & Competitive product prices & -2 \\
\hline \multicolumn{1}{|c|}{ Average } & $\mathbf{4 , 2 5}$ & \multicolumn{1}{|c|}{ Average } & $\mathbf{- 3 , 5}$ \\
\hline Competitive Position (CP) & -2 & Capacity & 5 \\
\hline Service Quality & -3 & Financial Stability Position (IP) & 5 \\
\hline Customer Loyalty & -3 & Productivity & 5 \\
\hline Technology Excellence & -2 & Available human resources & 4 \\
\hline Market Share & $\mathbf{- 2 , 5}$ & Average & $\mathbf{4 , 7 5}$ \\
\hline Average & &
\end{tabular}

From the matrix above, it can be known its $\mathrm{X}$ and $\mathrm{Y}$ axes as follows:

$$
\begin{aligned}
& \mathrm{X} \text {-axis } \quad=\text { Average } \mathrm{CP} \text { score }+ \text { Average IP score } \\
& =(-2,5)+4,75 \\
& =+2,25 \\
& \text { Y-axis } \quad=\text { Average FP score }+ \text { Average SP score } \\
& =4,25+(-3,5) \\
& =+0,75
\end{aligned}
$$

From the result of SPACE matrix, Freelens Studio is currently in an aggressive position, where Freelens Studio is in a good position. Therefore, the company is expected to use its internal strengths to take advantage of external opportunities, overcome internal weaknesses and avoid external threats. Therefore, back integration strategies, future integration, market penetration, market development and product development or combination strategies can all be selected depending on the conditions and capabilities owned and faced by the company.

\section{Internal-External Matrix Analysis (IE)}

Based on IFE and EFE matrix analysis, Freelens Studio scored 2.95 for internal factors and 2.3 for external factors. This indicates that the internal and external factors are in a moderate or average position. Which means that the internal-external matrix (IE) is in quadrant $\mathrm{V}$ or is in a hold and maintain state. In quadrant $\mathrm{V}$ position, it means that the company can use market penetration strategy and product development strategy. Market penetration is a growth strategy in which the company focuses on selling products to increase the market share of Freelens Studio. And also product development is a growth strategy where companies use this strategy to increase product sales by adding, improving, or introducing products to the market. 
International Journal of Entrepreneurship, Business and Creative Economy (IJEBCE), Vol. 1 (1), 39-56 Digital Marketing Strategy of Creative Consultant during CoVID-19 Pandemic: a Qualitative Approach Karerin Narisa Putri, Daniel Hermawan

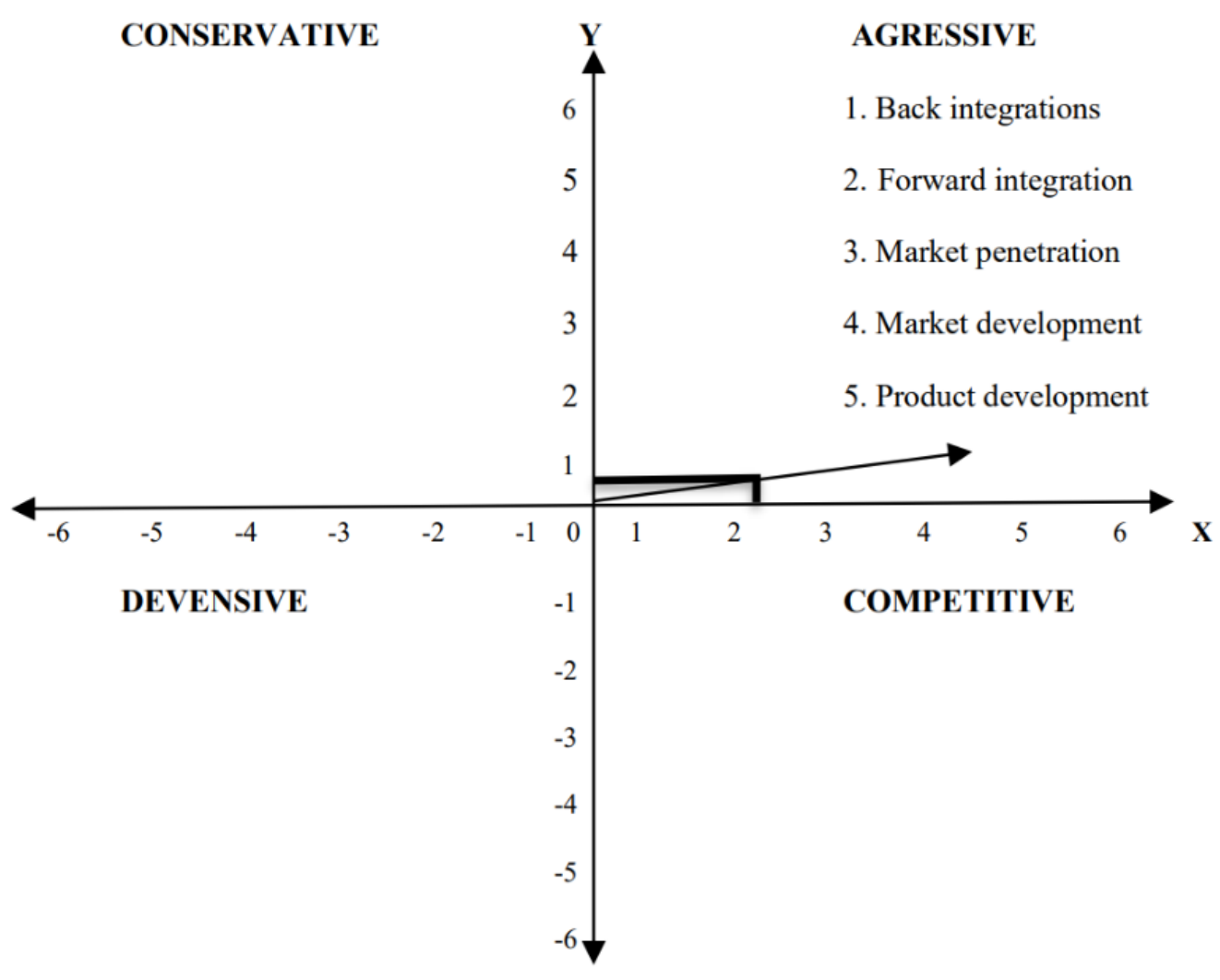

Figure 3: SPACE Matrix

\begin{tabular}{|c|c|c|c|c|}
\hline & \multicolumn{3}{|c|}{ Total IFE } \\
\hline & & $\begin{array}{l}\text { Strong } \\
3,0- \\
4,0 \\
\end{array}$ & $\begin{array}{l}\text { Mediu } \\
\text { m2,0- } \\
2,99 \\
\end{array}$ & $\begin{array}{l}\text { Weak } \\
1,0- \\
1,99\end{array}$ \\
\hline \multirow{3}{*}{ 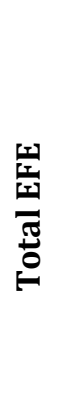 } & 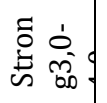 & I & II & III \\
\hline & 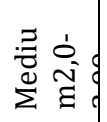 & IV & V & VI \\
\hline & $\begin{array}{l}\frac{\pi}{\pi} \\
3 \\
3\end{array}$ & VII & VIII & IX \\
\hline
\end{tabular}

Figure 4: IE Matrix 
International Journal of Entrepreneurship, Business and Creative Economy (IJEBCE), Vol. 1 (1), 39-56

Digital Marketing Strategy of Creative Consultant during COVID-19 Pandemic: a Qualitative Approach Karerin Narisa Putri, Daniel Hermawan

Based on the advice of the IE matrix, Freelens Studio can maximize its market penetration strategy to expand the scope of the service market share owned by Freelens Studio. This can be done by improving marketing strategies by increasing costs for advertising. Because so far, Freelens Studio is still less utilizing paid online advertising on social media. Freelens Studio only promotes its film UNSEEN with paid online advertising on social media, therefore Freelens Studio needs to increase its marketing efforts towards its own services and take advantage of paid advertising online on social media. Promotional activities can be campaigns and create unique and creative ads. While product development strategy is the company's effort to increase sales by adding, improving products that have been offered to the market. Based on SWOT analysis, Freelens Studio can take advantage of the current state of opportunity because nowadays many businesses need digital services to market their products. Therefore, Freelens Studio can develop services, and also develop more varied types of services to balance the needs of businesses today. The implementation of this strategy can run well if Freelens Studio is strong in its target market management capability and always evaluates the services offered so that Freelens Studio can know what the lack of services offered in order to succeed in business competition.

\section{Grand Strategy Matrix Analysis}

Based on Grand Strategy Matrix, Freelens Studio is in Quadran 1 because Freelens Studio has a strong competitive position along with a rapid market growth rate. In this case, Freelens Studio is in a strategic position because it is in a market that has strong competition and fast movement. Since Freelens Studio is in quadran 1 position, for the company in that position continue to concentrate on the current market, namely market pentration strategy and product development is the right strategy.

\section{QSPM Matrix Analysis}

After obtaining alternative strategies based on the results of the Grand Strategy Matrix, we used QSPM analysis in order to help companies to get the best alternative strategies before strategy assignments were made. Alternative strategies taken based on the Grand Strategy Matrix are market penetration strategies and product development strategies. In this QSPM analysis, we compare two alternative strategies that can be described in Table 8.

Based on QSPM analysis conducted through interviews with Freelens Studio owner, market penetration strategy gets a total of 6.3 while product development strategy gets a total of 5.6. This shows that market penetration strategy is a more attractive alternative strategy than product development strategy for owner of Freelens Studio. With the results of QSPM analysis on market penetration strategy is more appropriate, because it illustrates that the strategy used by Freelens Studio is appropriate and the results of interviews with the owner of Freelens Studio that the company is more focused on market penetration strategy because given the high level of competition, Freelens Studio will maintain or increase market share and increase competitiveness. That can be achieved with a combination of competitive pricing strategies, advertising, and sales promotions. Therefore, market penetration strategy is rightly chosen to reach market share that has not previously been reached by Freelens Studio. 
International Journal of Entrepreneurship, Business and Creative Economy (IJEBCE), Vol. 1 (1), 39-56 Digital Marketing Strategy of Creative Consultant during COVID-19 Pandemic: a Qualitative Approach Karerin Narisa Putri, Daniel Hermawan

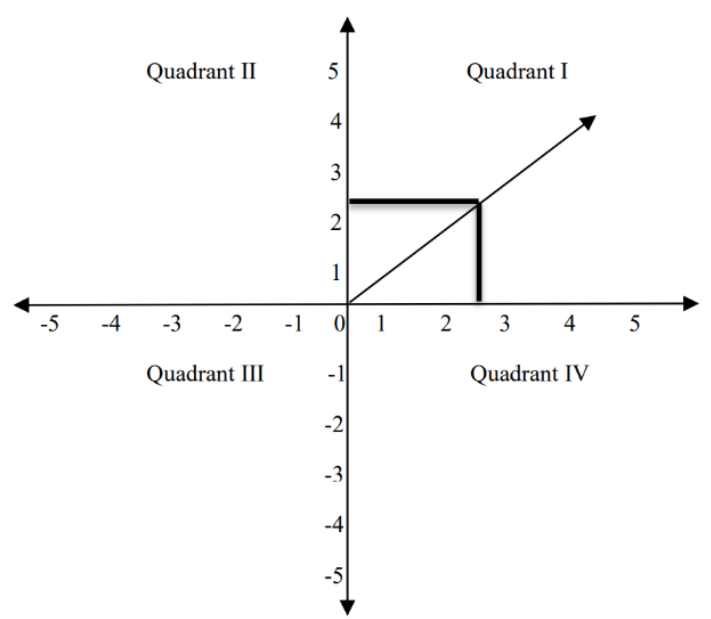

Figure 5: Grand Strategy Matrix

Table 8. QSPM Freelens Studio Matrix

\begin{tabular}{|c|c|c|c|c|c|}
\hline \multirow[t]{3}{*}{ ALTERNATIVE STRATEGIES } & \multirow{3}{*}{ Weights } & \multicolumn{2}{|c|}{$\begin{array}{c}\text { MARKET } \\
\text { PENETRATION }\end{array}$} & \multicolumn{2}{|c|}{$\begin{array}{c}\text { PRODUCT } \\
\text { DEVELOPMENT }\end{array}$} \\
\hline & & \multirow[t]{2}{*}{ AS } & \multirow[t]{2}{*}{ TAS } & \multirow[t]{2}{*}{ AS } & \multirow[t]{2}{*}{ TAS } \\
\hline & & & & & \\
\hline Have a clear organizational structure & 0,2 & 3 & 0,6 & 3 & 0,6 \\
\hline Flexible work ecosystem & 0,2 & 3 & 0,6 & 2 & 0,4 \\
\hline Have creative and innovative human resources & 0,25 & 4 & 1 & 4 & 1 \\
\hline \multicolumn{6}{|l|}{ Weakness } \\
\hline Limited networking & 0,05 & 2 & 0,1 & 2 & 0,1 \\
\hline Limited capital in technology investment & 0,2 & 3 & 0,6 & 4 & 0,8 \\
\hline Limited service type & 0,1 & 3 & 0,3 & 2 & 0,2 \\
\hline TOTAL IFE & 1 & & & & \\
\hline \multicolumn{6}{|l|}{ Opportunities } \\
\hline $\begin{array}{l}\text { COVID-19 pandemic boosts digital marketing } \\
\text { business }\end{array}$ & 0,2 & 3 & 0,6 & 3 & 0,6 \\
\hline $\begin{array}{l}\text { Development of technology and information in } \\
\text { the creation of digital content marketing that } \\
\text { continues to grow }\end{array}$ & 0,2 & 3 & 0,6 & 4 & 0,8 \\
\hline Launch a new product or service & 0,2 & 3 & 0,6 & 2 & 0,4 \\
\hline \multicolumn{6}{|l|}{ Threats } \\
\hline Competitors of similar companies & 0,1 & 4 & 0,4 & 3 & 0,3 \\
\hline $\begin{array}{l}\text { Lack of awareness of Consumer Product } \\
\text { Knowledge }\end{array}$ & 0,2 & 3 & 0,6 & 1 & 0,2 \\
\hline
\end{tabular}


International Journal of Entrepreneurship, Business and Creative Economy (IJEBCE), Vol. 1 (1), 39-56

Digital Marketing Strategy of Creative Consultant during COVID-19 Pandemic: a Qualitative Approach Karerin Narisa Putri, Daniel Hermawan

\begin{tabular}{|c|c|c|c|c|c|}
\hline $\begin{array}{l}\text { Declining business dynamics of the business } \\
\text { world }\end{array}$ & 0,1 & 3 & 0,3 & 2 & 0,2 \\
\hline TOTAL EFE & $\mathbf{1}$ & & & & \\
\hline TOTAL & & & $\mathbf{6 , 3}$ & & 5,6 \\
\hline
\end{tabular}

Notes: AS (Attractiveness Score); TAS (Total Attractiveness Score)

In addition, through paid advertising on social media, Freelens Studio has also pitched to milking agencies through networking. Therefore, to expand Freelens Studio's market share, Freelens can conduct promotions through submissions to large companies that have never previously done digital marketing.

In determining the market penetration strategy, Freelens Studio has weaknesses that can be an obstacle for Freelens Studio itself, namely technology that needs to be updated, because when the current technology is growing, and the opportunities demand for businesses who increasingly need digital services Freelens Studio needs to update the technology for its service needs in order to win business competition.

\section{CONCLUSION}

Digital marketing that has been used by Freelens Studio is through social media and e-mail. The main marketing tool and the focus for its digital marketing activities is through Instagram. Instagram is rated by Freelens Studio as a platform that is widely used by people today, making it easier to execute strategies and attract audiences and target clients. Through social media, Freelens Studio markets its services by using content marketing strategies, content marketing strategies are carried out to build brand awareness by involving visual and design in communicating message.

The type of content mostly created by Freelens Studio is infographic content by utilizing trending topics to be used as content. The content created is also not only marketed in Instastories, other content is posted in feeds with carousel format. Carousels allow social media users to digest information that was initially limited to one square-shaped visual into multiple series. As a result, the process of conveying information becomes more developed and more creative. Freelens Studio's success rate in digital marketing strategy is quite effective in marketing its services judging by promotional and advertising strategies and number of clients obtained this year. However, compared to the previous year, the number of clients and working capital this year is considered unfavorable to the company during COVID-19 pandemic. But Freelens Studio continues to develop its services with a variety of strategies to market its services by expanding its market share.

Based on QSPM matrix, market penetration strategy is more appropriate done by Freelens Studio, because it illustrates that given the high level of competition, Freelens Studio needs to maintain or increase market share and increase competitiveness. That can be achieved with a combination of competitive pricing strategies, advertising, and sales promotions. Therefore, the right market penetration strategy was chosen to reach market share that had not previously been reached by Freelens Studio.

Freelens Studio needs to increase its marketing efforts by increasing costs for advertising to increase and expand Freelens Studio's market share. Freelens Studio needs to expand its marketing efforts by creating more attractive advertising content and utilizing online marketing tools or paid advertising on Instagram, search engines such as Google, to maximize Freelens Studio's promotional and advertising activities as part of its market penetration strategy.

Freelens Studio also can launching a product in the form of collaboration with a brand or company. For example, collaboration with influencers, food brands, fashion, and so on. Product collaboration can be in the form of collaboration with a business in another field and Freelens Studio as an ad maker of the business and can also be the launch of a product from another business brand but a product design created by Freelens Studio. This collaboration activity is carried out 
International Journal of Entrepreneurship, Business and Creative Economy (IJEBCE), Vol. 1 (1), 39-56

Digital Marketing Strategy of Creative Consultant during COVID-19 Pandemic: a Qualitative Approach Karerin Narisa Putri, Daniel Hermawan

todevelop connections to merge companies to further develop, gain new audiences, expand markets, new innovations, and expand the Freelens Studio business network.

As technology grows, services requested or provided to clients must also adapt to current technology, and businesses increasingly need digital services. For example, the need for tools for production processes, such as software, cameras, lenses, computers, and so on. Freelens Studio needs to update technology for its service needs in order to win business competition.

In terms of social media marketing, Freelens Studio should not only prioritize its marketing strategy on Instagram, but Freelens Studio can be more active throughout social media that is widely used today, such as YouTube and Twitter. Freelens Studio can also do paid ads on other social media not only on Instagram. Freelens Studio also can increase the number of employees when the number of clients is quite large through outsourcing, so that the division of tasks can be in accordance with the number of capacity of clients and employees and does not cause double job desk, and the work process can be done effectively.

\section{LIMITATION \& FURTHER RESEARCH}

This research focuses on analyzing digital marketing strategies, not analyzing conventional marketing strategies in detail. Since research conducted during COVID-19 pandemic, the results and suggestions of this research need to adjust the situation and conditions of Freelens Studio. This research also only applicable for creative consultant with similar condition and situation.

\section{REFERENCES}

Agarwal, R., Animesh, A., \& Prasad, K. (2009). Social interactions and the "digital divide": Explaining variations in Internet use. Inform Systems Res, 277-294.

Ahuja, V., \& Medury, Y. (2010). Corporate blogs as e-CRM tools - building consumer engagement through content management. Journal of Database Marketing and Customer Strategy Management, pp.91-105.

Arzhanova, K. A., Beregovskaya, T. A., \& Silina, S. A. (2020). The Impact of the COVID-19 Pandemic on Consumer Behavior and Companies' Internet Communication Strategies. Proceedings of the Research Technologies of Pandemic Coronavirus Impact (RTCOV 2020) (pp. 50-57). Russia: Atlantis Press.

Aurfreiter, N., Boudet, J., \& Weng, a. V. (2014). Why Marketers Keep Sending You E-mails . McKinsey Quaterly.

Baltes, L. P. (2016). Inbound Marketing - the most important digital marketing strategy.

Bulletin of the Transilvania University of Brasov.

Berman, R., \& Katona, Z. (2013). The Role of Search Engine Optimization in Search Marketing. Marketing Science, 644-651.

Bruhn, M., Schoenmueller, V., \& Schäfer, D. (2012). Are social media replacing traditional media in terms of brand equity creation? Management Research Review, pp. 770-790.

Chapman, M. (2011, May 31). What Clicks Worldwide? Retrieved from Adweek . Christodoulides, G. (2009). Branding in the post-internet era. Marketing Theory, pp.141-144. Cresswell, J. (2008). Educational Research. Pearson-Prentice Hall.

Diandra. (2020). Kominfo. Retrieved from Kementrian Komunikasi dan Informatika Republik Indonesia: https://www.kominfo.go.id/content/detail/8637/pemerintah-ingin-media-sosialdimanfaatkan-untuk-hal-produktif/0/sorotan_media

Draskovic, N., \& Valjak, A. (2012). The 4Cs of the Croatian public healthcare system: Social marketing challenges at the dawn of EU accession. World Review of Enterpreneurship, Management and Suistainable Development, 221-235.

Gateway, B. (2018). Digital Marketing Strategy Guide : Intermediate Level. In D. Scotland,

Digital Boost : power up your business (pp. 16-17). Scotland: Business Gateway.

Glavas, C., \& Mathews, S. (2014). How International Enterpreneurship Characteristics .

International Business Review, 5833-5841. 
International Journal of Entrepreneurship, Business and Creative Economy (IJEBCE), Vol. 1 (1), 39-56

Digital Marketing Strategy of Creative Consultant during COVID-19 Pandemic: a Qualitative Approach Karerin Narisa Putri, Daniel Hermawan

Gyath, A. J. (2020). Application of the 4Cs Marketing Mix in the Digital Environment. International Journal of Psychosocial Rehabilitation, Volume 24, Issue 10.

Hauser, J. R., Urban, G. L., Liberali, G., \& Braun, a. M. (2009). Website Morphing. Marketing Science, 202-223.

Järvinen, J., Töllinen, A., Karjaluoto, H., \& Jayawardhena, C. (2012). Digital and Social Media

Marketing Usage in B2B Industrial Sector . Marketing Management Journal, pp.102-117.

Kotler, P., \& Gary, A. (2014). Principles of Marketing. Global Edition, 27.

Machado, C., \& Paulo, J. D. (2016). MBA : Theory and Application of Business and Management Principles. Switzerland: Springer Nature .

Malhotra, A., Kubowicz Malhotra, C., \& See, A. (2013). How to create Brand Engagement on Facebook. MIT Sloan Management review, pp.18-20.

Moyle, C. (2012, October 30). How much time, money do small businesses spend on social media? Retrieved from Vertical Response : http://www.verticalresponse.com/blog/how-muchtime-and-money-do-small-businessesspend-on-social-media-infographic/

Patel, J., \& Malpani, A. (2020). Impact of Covid19 on e-marketing: An Early Stage Review.

International Journal of Advanced Science and Technology Vol. 29, No. 12s, 1774-1779.

Rayport, J. F., \& Jaworski, B. J. (2001). E-commerce. New York: McGraw-Hill, 116.

Rishika, R., Kumar, A., R., J., \& Bezawada, R. (2013). The Effect of Customers. Information Systems Research, pp.108-127.

Rust, R., Lemon, K., \& Narayandas, D. (2004). Customer Equity Management.

Santoso, R. (2020). Review of Digital Marketing \& Business Sustainability of E-Commerce

During Pandemic Covid19 In Indonesia. Jurnal Ilmu Ekonomi Terapan, Vol. 5, No.2, 36-48.

Simmons, G. (2007). I-branding: developing the internet as a branding tool. Marketing Intelligence and Planning, pp. 544-563.

Steel, E. (2009). Marketers Take Search Ads beyond Search Engines. Wall Street Journal . Sugiyono. (2014). Metode Penelitian Bisnis. Jakarta: Alfabeta.

Sugiyono. (2018). Metode Penelitian Kualitatif. Bandung: Alfabeta. Sullivan, E. A. (2010). Targeting to the Extreme. Marketing News.

Taiminen, H., \& Karjaluoto, H. (2015). The Usages of Digital Marketing Channels in SMEs.

Journal of Small Business and Enterprise Development , 633-651.

Wang, C., \& Zhang, P. (2012). The evolution of social commerce: the people, management,technology, and information dimensions. Communications of the Association for Information Systems, pp. 1-23.

Wang, K., Wang, Y., \& Yao, J. (2005). A Comparative Study on Marketing Mix Models for Digital Products. Proceedings of the First International Conference on Internet and Network Economics, 660- 669.

Yang, C., Tang, X., Dai, Q., Yang, H., \& Jiang, L. (2013/2014). Identifying implicit and explicit relationships through user activities in social media. International Journal of Electronic Commerce, pp. 73-96.

Yasmin, A., Tasneem, S., \& Fatema, K. (2015). Effectiveness of digital marketing in the challenging age: An empirical study. International Journal of Management Science and Business Administration, 69-80. 